\title{
O temazcal entre passado e presente
}

Leda Peretti*

PERETTI, L. O temazcal entre passado e presente. Revista do Museu de Arqueologia e Etnologia, São Paulo, 19: 285-307, 2009.

Resumo: $\mathrm{O}$ presente trabalho faz parte de uma reflexão sobre o fenômeno do Ressurgimento Maia e, em especial, sobre o seu desejo de integração entre a medicina tradicional e a medicina oficial. Neste trabalho, a discussão limitou-se às práticas tradicionais das comadronas de língua maia por ocasião do parto e focalizou-se a atenção principalmente no temazcal. Lançando mão da análise histórico-religiosa, indagou-se sobre os significados que esta instituição tinha na época pré-colombiana e delineou-se, ainda que sumariamente, a sua evolução no decorrer do tempo. Em uma relação dialética com a visão de mundo ocidental, o temazcal transformou-se, conforme os resultados a que nos conduziu a nossa análise, de teatro de uma tensão com o inframundo, para permitir que emergisse e fosse posteriormente "re-criada" culturalmente uma nova vida, a lugar que libera o "calor" indispensável ao aquecimento da puérpera, que no parto atinge o seu estado de máximo frio (Guatemala) ou a lugar místico no qual vivenciar um contato com a Mãe Terra (México).

Palavras-chave: Temazcal - Comadronas - Parto - Binômio quente/frio.

\section{Introdução}<smiles>[AlH2]</smiles>
s populações indígenas do planalto da Guatemala crêem, de maneira bastante uniforme, que o banho de vapor, o temazcal, sirva para aquecer a puérpera que, no parto, atinge o momento de maior frio da sua existência. De fato, crê-se que o estado de "frio" atingido nesta ocasião seja o máximo, em termos de intensidade, que um ser humano possa experimentar.

(*) Verona, Itália. Graduação em "Religiões dos Povos Primitivos” na Universidade de Roma. Diplomada pela Universidade Iberoamericana de Cidade do México em “Desenvolvimento Sustentável”. lperetti@hotmail.com
O banho de vapor é tradicionalmente efetuado no temazcal. ${ }^{1}$ Este é uma estrutura externa à habitação, em geral de forma retangular, medindo aproximadamente $4 \mathrm{~m} \times 2 \mathrm{~m}$. O acesso ao temazcal dá-se através de uma abertura muito baixa, tanto que, para entrar, é preciso abaixar-se; uma vez dentro, não é possível voltar à posição ereta. Sobre a porta de acesso é frequentemente pendurada uma efígie da Virgem ou de algum santo.

Dentro do temazcal encontra-se uma bancada de terra queimada, portanto muito

(1) Em língua quiché chama-se tuj; em língua Mam, chuj, mas a sua estrutura não sofre variações significativas. 
dura, onde a paciente deve deitar-se. O calor liberado no temazcal é produzido por um jato d'água sobre pedras ardentes, aquecidas pelo fogo que a própria comadrona, ou os parentes, de fora, mantêm aceso. No planalto guatemalteco, um temazcal pode alojar, em média, duas ou três pessoas. Nesta área, a proporção de temazcal por habitação é de um temazcal para cada quatro casas e, portanto, várias famílias usam um mesmo temazcal.

É digno de nota que, hoje em dia, o temazcal seja utilizado não somente no parto, mas também para curar várias doenças (por ex., tifo, varicela, reumatismo, infecções dermatológicas, "problemas de nervos") e com finalidades higiênicas. Como escrevem autores espanhóis em um estudo sobre a transformação do temazcal na Mesoamérica do período préhispânico até nossos dias, «a finalidade higiênica é, talvez, uma das principais atualmente, e nela, inevitavelmente, a secularização e a dessacralização são processos em marcha, mais ou menos avançados, conforme os lugares ou regiões. Entre os Totonacas do México, por exemplo, entra-se no temazcal para lavar-se e relaxar-se, em geral uma vez por semana: no sábado ou na véspera de dias de festa» (Alcina Franch, Ciudad Ruiz, Iglesias Ponce de León 1969:121).

Do temazcal encontram-se vestígios arqueológicos em toda a área meso-americana. Em algumas cidades maias vieram à luz temazcales de grandes dimensões, que podiam hospedar até trinta pessoas; estes se situavam na área cerimonial, ao lado da quadra de jogo de bola. Os arqueólogos concordam sobre o fato de que no passado essa estrutura tivesse função ritual. Esta convicção é também confirmada pelo fato de que os missionários cristãos tentaram, desde os tempos da Conquista, suprimir o uso do temazcal, considerado lugar em que se realizavam ações contrárias à religião cristã.

No passado, as estruturas destinadas a temazcal podiam ser até subterrâneas ou semisubterrâneas e, neste caso, o acesso era feito através de uma escada. Atualmente, os temazcales são construídos na superfície.

Ao contrário do que se verifica na realidade contemporânea guatemalteca, em que o temazcal é muito difuso nas frias montanhas do planalto guatemalteco, no período pré-hispânico os temazcales eram mais numerosos nas terras quentes da planície. Este ponto é muito importante, porque coloca já uma primeira interrogação sobre a função de fornecer calor à puérpera e, em geral, ao doente, conforme a explicação corrente hoje em dia.

O temazcal, porém, serve também para aquecer o recém-nascido: acredita-se de fato que, nas primeiras fases da sua existência, o ser humano esteja em uma condição "fria", que progressivamente transforma-se em "quente", com o aumentar da idade. No período da maturidade, o indivíduo atinge um equilíbrio entre "quente" e "frio" (está em uma condição de neutralidade em relação a estas duas categorias) e, com o passar dos anos, perde gradualmente o seu "calor".

As concepções guatemaltecas em relação ao parto podem ser resumidas da seguinte forma: o temazcal tem a função principal de reforçar e endurecer as carnes e a pélvis macia da puérpera; aquecer/cozinhar a mãe e a criança; cozinhar o leite materno e facilitar-lhe o fluxo. A massagem prénatal tem, por sua vez, o objetivo de preparar a mãe e mantê-la quente, enquanto que aquela post partum propõe-se a juntar os ossos da mulher e aquecê-la. A faixa colocada sobre o abdome da mulher serve, por fim, para fazer aderir o útero ao corpo e fazer sair todo o sangue (Villatoro 1994; Hurtado 2005; Cosminsky 2001; Mosquera Saravia 2001; Wilson 1999; Alcina Franch 2000; Ciudad Ruiz; Alcina Franch; Ponce De Léon 1980; Lillo Macina 2007; Foster 1994).

Se os significados da faixa e da massagem parecem suficientemente imediatos, resta a ser compreendido o motivo pelo qual o "calor" liberado pelo temazcal e pela massagem seja considerado fator indispensável à recuperação post-partum e, em sentido mais amplo, do restabelecimento da saúde.

(2) Note-se que, em relação a esta última concepção, verificam-se variações de um grupo a outro. Wilson, por exemplo, observa que, para os Cakchiquel que estudou, o avançar da idade coincide com o aumento do "calor": o idoso, como a pessoa de classe alta e os especialistas da medicina e dos rituais, são considerados possuidores de um "calor" maior do que aquele possuído pelos jovens (Wilson 1999:111). 
Para procurar uma resposta a esta interrogação, foi necessário alargar as fronteiras da nossa pesquisa.

Antes de mais nada, dirigimos o olhar para as crônicas sobre o temazcal contemporâneas à Conquista para compreender que significados pudesse ter no pasado; os resultados a que chegamos nesta primeira exploração indicaramnos o caminho que nossa pesquisa devia empreender para seguir adiante.

Para encontrar elementos que nos pudessem orientar na compreensão do temazcal préhispânico, recorremos à longa e detalhada descrição do parto contida na Historia General de las cosas de Nueva España, de Sahagún, ainda que a mesma trate das populações astecas do período contemporâneo à Conquista. Esta escolha deriva do fato de que esta obra é, em relação à matéria, a mais acurada de seu tempo. ${ }^{3}$

A partir do texto em questão não podemos chegar à conclusão de que os significados atribuídos ao temazcal fossem os mesmos nas outras culturas da Mesoamerica e nas diversas épocas precedentes à Conquista. Parece-nos, porém, lícito pensar que, dado que os diferentes povos da Mesoamérica compartilhavam uma mesma cosmogonia, divindades comuns ou passíveis de sobreposição, uma contagem do tempo igual, estilos artístico-arquitetônicos e sistemas de escritura semelhantes, também os significados associados ao nascimento - evento extremamente importante para o indivíduo e a sociedade e portanto objeto de uma intensa elaboração simbólica em correlação com a cosmogonia fossem, nas diferentes culturas, muito semelhantes.

\section{As comadronas e o parto no tempo da Conquista}

Conforme Sahagún, na civilização asteca a hora do parto era chamada "a hora da morte":

(3) A descrição do nascimento, contida no texto de Sahagún, refere-se a um membro de alta extração social. Com base nas informações contidas neste texto, não è possível estabelecer se as concepções e os rituais relativos ao nascimento fossem os mesmos para todas as classes sociais. se o parto transcorria bem, todos ficavam alegres dizendo que "a mãe tinha vencido masculinamente" e que tinha "capturado" uma criança. A comadrona era chamada, como hoje, “aquela que recebe" (Sahagún 1999: 383).

Coerentemente com a idéia de instabilidade do cosmos e da luta contínua entre princípios opostos - idéia comum a todo o corpus mitológico mesoamericano - parece que os Astecas acreditavam que o dar à luz fosse uma batalha cujo resultado era imprevisível.

Além da assimilação do momento do parto à guerra, parece que se exprimia também outra idéia, a de que da gestação participassem tanto os senhores do céu quanto os do inframundo: os primeiros presenteavam uma pedra preciosa, uma pluma rica, que os últimos, do mundo subterrâneo, podiam "fazer germinar e florir". Diz o texto que aquilo que, por ventura, viesse a germinar e florir era o que os mortos, para sempre no mundo da obscuridade, «dejaron plantado, así como maguey ${ }^{4}$ que dejaron plantado profundamente, que fue el deseo que tuvieron que se multiplicase su generación» (Sahagún 1999: 368).

Conforme o que se deduz dos relatos de Sahagún, são as divindades do céu a guardar consigo as potencialidades da vida humana, mas são as divindades associadas à morte aquelas que traduzem esta potencialidade em realidade e permitem, portanto, que no corpo da mulher "germine" uma nova criatura. A forma que esta criatura assumirá no decorrer da gestação dependerá principalmente do sêmen masculino: será de fato o marido a ter o dever de alimentar o feto com o próprio líquido seminal.

Mas como se articulava o "desejo" dos pais de reviver nos filhos, com a idéia de uma germinação da pedra preciosa no mundo dos mortos e de uma batalha final com os senhores do inframundo?

Percorramos passo a passo as idéias ligadas

(4) $O$ maguey è un tipo di cactus, também conhecido como agave (sisal), ou aloé americano. Ainda cultivado pelo seu látex branco, do qual extrai-se uma bebida alcoólica (pulque), em outros tempos era ligado a divindades associadas à fertilidade. Os espinhos do maguey eram utilizados, por sua vez, nos ritos de auto-sacrifício. 
à formação de uma nova vida, conforme Sahagún.

Assim que uma mulher sabia que estava grávida, reuniam-se em um banquete seus pais, os pais do marido e os notáveis da aldeia para agradecer a Yoalli Ehécatl, "que quiere decir tiniebla y aire, y que está en todo lugar", que deu vida até os nossos dias e que é aquele que tirou os progenitores da terra e os colocou no lugar da obscuridade. (Sahagún 1999: 366-367).

Ao deus agradecia-se pela "misericórdia de ter desejado colocar dentro da mulher una piedra preciosa y una pluma rica".

Uma vez ocorrido o parto, felicitando-se com a gestante, dizia-se:

«Por ventura es verdad que nuestro señor

Quetzalcóatl, que es criador y hacedor, os ha hecho esta merced. Por ventura lo ha determinado el que reside en el cielo, un hombre y una mujer, que se llaman Ometecuhtli, Omecihuatl» (Sahagún 1999: 369).

No discurso de agradecimento pelo novo evento, continuava-se explicando:

«Por ventura ya quiere brotar la generación de tus bisabuelos y tatarabuelos, y de tus padres que te echaron acá, y nuestro señor dios quiere que engendre y produzca fruto el maguey que ellos plantaron hondamente, para que lo que naciere sea imagen de ellos, a los cuales el mismo nuestro señor los escondió y los llevó para sí, y el quiere que los levanten la cabeza y en alguna manera los resuciten los que nacerán de su posteridad.» (Sahagún 1999: 370).

Que conceitos desejava-se exprimir, lançando mão de alguns atributos de Yoalli ehécatl, Quetzalcoatl, Ometecuhtli e Omecíhuatl, Yoaltucitl... e contemporaneamente sugerindo uma estreita relação entre "o nosso senhor que presenteia a pedra preciosa, a pluma rica" e o reino dos mortos?

Nas longas orações e nas conversas entre a comadrona, o novo casal, os pais de ambos e os notáveis reunidos para congratular-se pelo novo evento, as denominações em língua nahuatl das divindades são de fato frequentemente substituídas pela perífrase "nosso senhor", à qual se acrescenta muitas vezes "que está em todos os lugares". Entretanto, a partir da leitura atenta deste texto, nota-se que "o senhor que está em todos os lugares" (muitas vezes traduzido no plural "senhores") e que presenteia "a pedra preciosa, a pluma rica", é efetivamente associado ao reino dos mortos. ${ }^{5}$

A nossa discussão, iniciada com o temazcal, teve, portanto, de procurar explicações para esta constante referência ao reino da morte. $\mathrm{O}$ ponto de partida da nossa pesquisa foram justamente as divindades invocadas pela comadrona.

Como é de conhecimento geral, para a população asteca, a superfície terrestre era habitada pela humanidade. Acima dela havia vários estratos, ou céus, dos quais o último era o Omeyoacan, o reino da "Dualidade". Esta entidade, por sua vez, dividia-se em duas divindades, Ometecuhtli, "Senhor Dois", e Omecíhuatl, "Senhora Dois". Abaixo do nível terrestre, imaginado como flutuante sobre águas cósmicas, encontravam-se os estratos do mundo subterrâneo, presidido por Mictlantecuhtl. ${ }^{6}$

As divindades da Mesoamérica não estavam organizadas em um panteão estruturato hierarquicamente, não tinham características estabelecidas de maneira rígida e uma individualidade absoluta: os seus atributos e nomes mudavam conforme as circunstâncias e as suas personalidades variavam constantemente

(5) Acreditamos que a perífrase "nosso senhor que reside em todas as coisas" fosse um acréscimo do curador do texto, ou seja Sahagún, e derivasse da sua impossibilidade ou incapacidade de conceber ideias sobre o nascimento da vida tão diversas daquelas cristãs. Ainda que, de fato, as numerosas seções que constituem a Historia General derivassem da colaboração de sábios provenientes da aristocracia indígena, fato que confere uma profundidade e uma riqueza de detalhes únicas em relação a todas as outras descrições da época, provavelmente a supervisão e a correcção da obra final cabiam a Sahagún. Desta redação final - que obedecia, em última instância, à finalidade principal do trabalho missionário, isto é, a evangelização das terras conquistadas - deduz-se que derivem várias incongruências, entre as quais aquelas de que falamos acima. (6) Os estudiosos da matéria não concordam em relação ao número de estratos do plano celeste (para alguns são doze, para outros treze, ou nove), enquanto que são praticamente unânimes em reconhecer ao mundo subterrâneo nove estratos. 
seguindo a dinâmica do contexto. Uma das principais características das divindades, a ambiguidade, servia, de fato, como registro semântico para qualificar os diversos aspectos e circunstâncias da realidade. O movimento, e portanto a idéia de alternância entre os diversos elementos e âmbitos, eram os princípios centrais do cosmos. Como escreve Eduardo Natalino dos Santos, "Os âmbitos cosmográficos eram delimitados por fronteiras graduais e transponíveis, que serviam antes para marcar a circulação e o movimento dos entes e do tempo pelo espaço do que para estabelecer o mapa de um Universo fixo e imutável." (Santos 2005: 414). O próprio senhor supremo do mundo subterrâneo da morte e da escuridão, Mictlantecuhtli, era, para citar um exemplo, também senhor do sexto céu; a deusa Yoaltucitl, para lembrar um outro caso, residia acima dos nove céus, mas era também Senhor da noite.

Tentemos, então, compreender os significados atribuídos, pela cultura asteca, ao nascimento, começando por identificar as características que de cada uma das divindades queria-se enfatizar, uma vez que consideradas pertinentes à qualificação deste evento.

Yoalli Ehécatl, também chamado Vento da Noite e 9-Vento, era uma das divindades principais no tempo da Conquista. Surgiu provavelmente no período Clássico entre as populações do Golfo do México, tornou-se depois uma das principais divindades em Tula e, no período Pós-Clássico (900-1500 d.C.), confundiu-se com Quetzalcoatl, sendo por este absorvido, a ponto de ser considerado uma das suas múltiplas manifestações.

Ehécatl, antes desta fusão, era um dos quatro criadores do cosmos, artífice da separação entre o céu e a terra, quando o cosmos estava ainda mergulhado no caos e nas trevas. Seu sopro foi o propulsor do movimento do Sol e da Lua e por isso mesmo da vida do cosmos (Sahagún 1999: 432).

Em seguida, Ehécatl adquiriu outras qualidades: tornou-se uma das manifestações de Quetzalcoatl, a Serpente Plumada, e, como este, assumiu características de herói cultural, isto é, daquele que transmitia aos homens os "mistérios da vida”, transitando entre o mundo noturno e o nivel terrestre. As esferas sobre as quais governava Ehécatl, o deus de rosto negro, de corpo humano e bico de pássaro, eram o canto, a poesia, a escrita, qualidades supremas a ele transmitidas pelo céu noturno e que ele manifestava sobre a terra. ${ }^{7}$

A figura de Quetzalcoatl era muito complexa e também a mais polimorfa de todo o panteão asteca. Seria suficiente dizer que, contendo em si o elemento celeste (ave, o quetzal) e o elemento ctônico (serpente, o coatl) era, por excelência, a divindade que, justamente por causa da sua duplicidade, podia mediar e, portanto, colocar em contato polos opostos.

Em uma versão presente nos códices do grupo Borgia, Quetzalcoatl desce ao inframundo, morre em uma fogueira e transforma-se em Vênus. A associação entre Quetzalcoatl e o planeta Vênus, cuja singular trajetória faz com que seja o primeiro astro a iluminar-se ao crepúsculo e o último a "se apagar" na manhã seguinte, depois de ter desaparecido do céu durante a noite, dá a Quetzalcoatl também o atributo de mediador entre a luz e as trevas.

Em razão da sua inicial e congênita dualidade, tornou-se assim, conforme alguns estudiosos, o deus que, por definição, podia absorver, em si, todas as outras oposições de que era pontilhado o pensamento mesoamericano na sua interpretação do mundo: morte/vida, luz/treva, terra/céu, feminino/masculino...

Esta capacidade de colocar em relação, isto é, em contato, qualificava Quetzalcoatl como deus da transformação, ou seja, da capacidade de traduzir em realidade atual o que existia somente como potencialidade.

(7) No texto de Sahagún, e mais precisamente na descrição da confissão anual dos pecados ligados à carnalidade e em relação à deusa Tlazolteotl, o penitente dirigia-se primeiramente a Yoalli Ehécatl, nesta ocasião identificado com Tezcatlipoca (Sahagún 1999:36-38). Este deus era uma das divindades principais dos Nahua, associado à guerra, ao céu noturno, ao inverno, ao norte. O seu nagual era o jaguar, isto é, o sol em seu aspecto noturno. Tezcatlipoca em vários mitos é o artífice, junto a Quetzalcoatl, da separação entre o céu e a terra e do nascimento de Cinteótl, cujo sacrifício dará origem ao deus do Milho (e, portanto, ao primeiro homem), à primeira luz do mundo e à estrela da manhã (Vênus). 
Poderia-se, então, supor que, no pensamento asteca, a dupla Ometecuhtli - Omecihuatl era a entidade que decidia sobre a existência de cada homem e Ehécatl-Quetzalcoatl era a dupla divina que traduzia estas potencialidades em ato real (Florescano 1995; Graulich 1990 e 1988; Scarduelli 1980: 179-214; Monaco 1997).

Na Leyenda de los soles, Quetzalcoatl é, além disso, o deus que dá origem à humanidade, indo ao mundo subterrâneo para recuperar os ossos dos seres humanos mortos anteriormente no dilúvio cósmico. Sobre estes ossos, trazidos à superfície através de vários estratagemas para induzir Mictlantecuhtli (senhor da morte) a cedê-los a si, Quetzalcoatl vai respingar gotas de sangue do seu membro viril: deste sacrifício, seguido pelos das outras divindades, nascerão os "vassalos dos deuses". Esta ação conclusiva é, porém, precedida pela intervenção da deusa Cihuacóatl-Quilaztli (aquela que governa o parto, a "Mãe Guerreira"), que tritura os ossos recuperados por Quetzalcoatl em um almofariz para que o deus possa sobre eles cumprir o seu sacrifício.

Parece, portanto, que, para a cultura asteca, o mundo subterrâneo é o lugar onde se realizam transformações de importância essencial para o cosmos. Uma concepção semelhante exprime-se também em âmbito maia. No Popol Vuh, o segundo par de gêmeos (Hunahpú e Ixbalanqué) encontra na morte em Xibalbá um renascimento, que permitirá que se transformem em Sol e Lua; ainda no inframundo, a morte do primeiro par de gêmeos (Hun-Hunahpú e Vucub- Hunahpú) transformará a árvore estéril em árvore rica de frutos e, sempre neste lugar, a caveira de Hunahpú fecundará a moça de Xibalbá (isto é, "morta") em mulher fecunda, aquela que, vindo à superfície, irá gerar os dois gêmeos do destino astral. Da mesma forma, na Leyenda de los soles, Quetzalcoatl deve descer ao mundo subterrâneo para resgatar os ossos dos homens, a partir dos quais, com o seu sangue, dará origem à humanidade. ${ }^{8}$

(8) Segundo Florescano, «este ciclo de muerte y resurrección de la planta del maíz estableció, para todos los pueblos mesoamericanos, el paradigma de los procesos de creación». (Florescano 1995:133). Segundo o Autor, a partir deste primeiro paradigma, todas
O frade Sahagún, que tantas vezes traduzia o reino subterrâneo de Mictlantecuhtli (equivalente asteca do Xibalbá dos Maia Quiché) como "Inferno", podia compreender, ou aceitar, idéias tão estranhas à concepção cristã sobre a criação e a procriação humana?

Talvez por causa desta distância que separava a Nova Espanha do Velho Mundo ao conceber a origem e o mistério da vida na concepção, no texto de Sahagún não há qualquer explicação sobre as substâncias que concretizavam, no corpo da mulher, a ligação entre os antepassados habitantes do lugar das trevas e as divindades residentes no plano celeste. $^{9}$

Em sua descrição, Sahagún conta que, quando a mulher acabava de parir, no momento seguinte ao novo nascimento, assim falava-se ao pai da criança:

«Nuestro piados dios, que está en todo lugar y por quién vivimos, ha enviado a este mundo una piedra preciosa, una pluma rica, que es vuestra imagen y vuestra sangre y vuestros cabellos, y vuestras uñas, y pedazo cortado de vos mismo".

as culturas agrícolas centro-americanas, nas quais o milho é o elemento essencial da dieta humana, definiram uma estrutura narrativa do mito em que, mesmo com a variação das vicissitudes dos protagonistas e dos objetivos, mantém constante o tema da descida ao mundo subterrâneo para obter bens essenciais à vida. Como o milho, que afunda suas raízes nas profundezas da terra e que frutifica na superfície, a criação de elementos vitais plasma-se neste modelo. Já Westheim, em 1957, tinha identificado no milho a base material do mito próprio da Mesoamérica da ressurreição ou renovação da vida (Westheim 1957:73, citado por Ruz Lhuillier 1968: 265).

(9) Segundo a interpretação de López Austin, a essência proveniente do céu poderia ter sido o tonalli, espécie de "sombra" do indivíduo guardada na cabeça, em relação com o Sol (Tonátiuth), e, portanto, com a energia (tona), com o fogo (tletl) e com o calor. A essência, por sua vez, que talvez viesse do mundo dos mortos, era o teyolia, espécie de "alma" do indivíduo, residente no coração, e que, por ocasião da sua morte, voltava ao reino subterrâneo. A terceira entidade anímica, ihiyotl, presente no homem - sempre conforme o Autor - residia no fígado, governava os sentimentos e as paixões e podia, em algumas circunstâncias, causar danos a terceiros (López Austin 1989: 223-262). 
Na passagem seguinte, continua-se dizendo: «Ha nacido y ha llegado a este mundo una piedra preciosa una pluma rica, que es planta y generación de nuestros señores, los reyes que pasaron y dejaron su generación como pedazos de sí mismos, que son sus cabellos y sus uñas; y es su sangre, y su imagen, ha brotado, ha florecido la fama y gloria que ha de resucitar la memoria y la gloria de sus antepasados, abuelos y bisabuelos, y los ha dado nuestro señor su imagen y su retrato» (Sahagún 1999: 392).

Assim, não obstante se sugerisse uma ligação entre mortos e vivos, no texto de Sahagún nunca se encontram, explícitas, idéias relativas à concepção. A interpretação segundo a qual uma centelha era colocada no ventre da mulher pela dupla Quetzalcoatl-Ehécatl por vontade de Ometecuhtli-Omecihuatl e fecundada pelo mundo subterrâneo, é somente uma entre as tantas possíveis. O que se encontra claramente expresso é apenas a convicção de que a nova criatura, contida no ventre materno, podia crescer através das relações sexuais: o sêmem do homem era, de fato, o alimento primário da criatura que residia no ventre da mulher (Sahagún 1999: 377 e 370). ${ }^{10}$

Se, no passado, o sangue era considerado o elemento primário para nutrir as divindades, seria admissivel pensar que, da mesma forma, fosse este mesmo elemento a fecundar o ventre "úmido e fresco" da mulher e a nutrir o seu feto. No texto de Sahagún não se encontram, entretanto, claras evidências que possam sustentar esta hipótese, assim como não se identificam descrições claras das idéias relativas à concepção. López Austin, o estudioso que mais se dedicou à correspondência entre ideologia pré-hispânica e corpo humano, propõe uma interpretação segundo a qual o processo de geração inicia-se através da união de dois líquidos, um proveniente do pai e o

(10) A comadrona explica à gestante, entre outras coisas, que as relações sexuais não devem ser muito numerosas, porque poderiam provocar a morte da mulher no parto; $o$ excesso de líquido viscoso e pegajoso pode, de fato, criar obstáculos à saída da criança. outro, equivalente, da mãe; todavia, ele admite que os nomes dados a tais líquidos não oferecem esclarecimentos sobre as características atribuídas aos mesmos. Quando se falava de hereditariedade, usava-se a metáfora "o sangue, a cor", enquanto que, quando se fazia referência especificamente ao sêmen masculino, diziase também «lo óseo que se coagula» (López Austin 1989: 190).

Na descrição de Sahagún não é de todo claro qual fosse a contribuição da mulher para o crescimento do feto. Poder-se-ia pensar que o líquido que "transmitia a imagem de seus antepassados", fosse o sangue menstrual, transformado em líquido "gerador" durante esta fase? ${ }^{11}$

Na descrição de Sahagún, a idéia que realmente é expressa com muita clareza é de que a semente masculina seja fundamental durante a gestação. Sahagún conta como a comadrona recomenda à mulher ter relações sexuais com o marido, uma vez que a abstinência nos primeiros meses de gravidez poderia fazer com que a criatura "saia doente e de forças escassas".

A idéia de que no modelo reprodutivo mesoamericano do passado a mulher não tivesse nenhum papel na concepção foi bem evidenciada por Sahagún, que descreve como a mãe não deveria acreditar ter qualquer mérito na mesma: gabar-se de ter uma vida no ventre teria significado provocar a ira das divindades, que a teriam punido com doenças ou até mesmo com a morte. Nas recomendações da comadrona à gestante é explícita a idéia de que a futura mãe seja o recipiente através do qual se

(11) Entre as várias recomendações, a comadrona acrescenta, com uma frase obscura, que a gestante deve comer o suficiente e com qualidade, «mayormente cuando a la preñada le viene su purgación, o como dicen, su regla, y esto llaman que la criatura se lava los pies porque no se halle la criatura en vacío o haya alguna vaciedad o falta de sangre o humor necesario, y así reciba algun daño». (Sahagún 1999: 378). Se corretamente interpretada, esta frase poderia querer dizer que o sangue, que normalmente sairia durante o mênstruo, na gravidez serve a alimentar a nova criatura e deve, portanto, ser abundante (tanto que "nele a criança possa lavar-se os pés"). Daqui a necessidade de uma alimentação melhor, recomendada pela comadrona. 
realiza a união de forças externas e independentes da sua vontade. $\mathrm{O}$ dever da mulher é não prejudicar, pelo contrário, tutelar $a$ pedra preciosa e a pluma rica que contém em si, expressão do desejo dos antepassados de um retorno ao mundo dos vivos. ${ }^{12}$

As proibições alimentares, o veto a ocuparse das lides domésticas, prescrições em que insistia tanto a comadrona, eram, assim, também voltadas a salvaguardar a sua saúde, mas marcavam sobretudo a suspensão do papel social da mulher, agora reduzida a recipiente da pedra preciosa e da pluma rica.

O papel da mulher tornava-se, porém, sumamente importante no parto, que, como já dissemos, assimilava-se à guerra: a mulher, assim como um guerreiro, tinha a missão de "capturar" ao além-mundo um novo ser, empresa que realmente sempre a "feria" e às vezes podia custar-lhe até a vida. Neste último caso, o recém-nascido órfão era denominado também "prisioneiro de guerra" e a mulher morta era chamada cihuateteo (deusa fêmea) e mocihuaquetzque ("guerreira de aspecto feminino"). ${ }^{13}$

Detenhamo-nos ainda um instante nesta imagem da mulher guerreira. Narra Sahagún que, quando uma mulher morria de parto, dizia-se que

era uma mulher valorosa, que com a sua morte tinha garantido para si a vida eterna... "Y aunque la muerte de estas mujeres, que se llamaban mocihuaquetzque, daba tristeza y lloro a las parteras cuando morian, los padres y parientes de ellas

(12) No texto, os elementos associados à regeneração dos defuntos são: espinhos de maguey (utilizados no autosacrifício), caña de humo (literalmente, cana de fumo), unhas e cabelos.

(13) As mulheres mortas no parto, ditas também Cihuateteo, moravam em Cihuatlampa, "Lugar das Mulheres", a oeste do cosmos, de onde saíam para escoltar, ou carregar sobre os ombros, o sol na sua fase descendente. Acreditava-se que fossem dotadas de poderes ambivalentes: assim como podiam ajudar os parentes em algumas de suas necessidades, podiam também provocar doenças (sobretudo epilepsia) nas mulheres e nas crianças durante as noites em que baixavam sob a forma de tzitzimime, seres espantosos e muito temidos. alegrábanse, porque decían que no iba al infierno, sino a la casa del sol y que el sol por ser valiente la había llevado para sì.

A casa do Sol, para onde as mulheres mortas de primeiro parto e na guerra ascendiam, era a do ocidente. A outra casa do Sol, a de oriente, era o destino post mortem mais feliz, prerrogativa das pessoas mais nobres e de mais alto status, isto é, dos guerreiros mortos em batalha, ou tomados prisioneiros e imolados sobre a pedra sacrificial.

O parto era, portanto, associado de tal forma a uma batalha a ponto de consagrar as mulheres que nele morriam à categoria de guerreiros mortos em batalha. Havia, porém, uma diferença substancial entre os destinos post mortem destas duas categorias de guerreiros: enquanto as almas dos soldados ajudavam o Sol a surgir das trevas e a subir aos céus, as das mulheres abriam-lhe a estrada em direção descendente, até as fronteiras do mundo subterrâneo. Já aqui é evidente um nexo simbólico entre a mulher e o mundo subterrâneo, o dos mortos.

Esta concepção, vista sob outra perspectiva, ajuda a colocar em relevo também outros fragmentos da lógica asteca: inversamente à guerra, prerrogativa exclusivamente masculina, em que o homem tinha o papel ativo de vivificar as divindades e in primis o Sol, através do sacrifício, a morte da mulher no parto não dependia da sua vontade e nem sempre era o prelúdio de uma nova vida - idéia esta expressa claramente também em Sahagún (1999:382). ${ }^{14}$ Enquanto perecida de "morte gloriosa", isto é, com a finalidade de gerar vida, a mulher morta no primeiro parto, assim como em guerra, merecia, então, elevar-se à casa do Sol e conquistar com isto a vida eterna, mas, uma vez que, na realidade, era "eleita" pelo mundo da morte, ou melhor, tendo sido pelo mesmo derrotada, podia aspirar somente à casa do céu, a do ocidente, que do mundo subterrâneo era $\mathrm{o}$ ingresso.

(14) «Esto (a morte da puérpera) cierto, no fue de vuestra voluntad, sino que fuisteis llamada, y siguiendo la voz del que nos llamó.» 
A ambiguidade da potência da mulher morta no parto é bem evidenciada também na descrição da batalha que as comadronas tinham que travar com os guerreiros da aldeia para conseguir enterrar o corpo da defunta. Sahagún faz questão de precisar que "não era uma batalha de brincadeira", era uma coisa séria: os guerreiros, com gritos e indumentária de guerra, atiravam-se sobre o corpo da mulher, tentando subtraí-la às comadronas, para apossessar-se do dedo médio e dos cabelos da mulher. Os bruxos, por sua vez, tentavam cortar-lhe o braço e a mão esquerda. Acreditava-se que estas partes do corpo, "conservadas como relíquias", infundissem coragem aos guerreiros e poderes mágicos aos feiticeiros (Sahagún 1999: 380-381). ${ }^{15}$ De la Serna, em seu livro quase contemporâneo do de Sahagún, dá-nos uma descrição curiosa sobre como era usado o braço subtraído às mulheres mortas de parto (De la Serna 1952: 169-170).

Venhamos agora ao temazcal. Em coincidência com o início do trabalho de parto, faziase entrar a mulher no temazcal. Na realidade, o seu primeiro banho de vapor acontecia durante a gravidez e era nessa ocasião que Sahagún descrevia o temazcal com maiores detalhes. $\mathrm{O}$ banho chamava-se também Yoalúcitl, do nome da divindade feminina, «madre de los dioses, diosa de los baños, sabedora de los secretos, en cuyas manos todos nos criamos» (Sahagún 1999: 374). Por sua associação com os mistérios do cosmos, Yoalúcitl ou Temazcaltui era a protetora da medicina e das ervas medicinais, invocada pelas comadronas, médicos e adivinhos. ${ }^{16}$

(15) Diz De la Serna: quando um grupo de ladrões decidiam saquear uma casa, dirigiam-se dançando à casa das vítimas, capitaneados por aquele que erguia uma imagem de $\mathrm{Ce}$ Ehecatl ou de Quetzalcoatl e, na outra mão, o braço roubado à mulher morta de parto. Chegando a seu destino, batiam com este último na porta. As pessoas no interior da casa ficavam atônitas, assistindo paralisadas ao roubo de seus bens, à violência contra as mulheres. Os ladrões, depois de cumprir todas as suas malfeitorias com calma e de terem-se demorado na casa a comer, saíam correndo. Quem, entre eles, caía no chão, não podia levantar-se até o nascer do sol, fato que fazia com que fosse descoberto o malfeito. (16) As celebrações da festa anual dedicada a esta
O temazcal era também chamado Xochicaltzin, "céu noturno" e "lugar das flores", e dizia-se que nele a senhora Yoalúcitl, já no terceiro ou quarto mês de gravidez, «arrecia y esfuerza los cuerpos de los niños».

Como em uma réplica do que hoje se diz, a comadrona afirmava que no temazcal «la diosa de las cosas secretas y aderenza las cosas desconcertadas, en los cuerpos de los hombres, y fortifíca las cosas tiernas y blandas».

Tudo aquilo que se realizava no temazcal era o que ainda hoje as comadronas fazem no mesmo: massagear o ventre para endireitar a criança, administrar infusões de ervas à parturiente e, em caso de risco, cortar em pedaços o feto para podê-lo assim extrair da mulher.

Em relação às condições físicas do temazcal, a comadrona preocupava-se que, em seu interior, a temperatura não fosse muito alta, "senão a criança poderia se queimar", e acrescentava que a massagem não devia ser muito enérgica, para evitar lesões à pluma rica.

Todas as artes e os cuidados de que a comadrona era capaz eram tentados, mas, ao final, ela concluía que o que aconteceria no temazcal não era dado a saber.

divindade são muito esclarecedoras da idéia subjacente à relação entre as diversas forças do cosmos, projeção do modelo cultural asteca, no qual o embate entre termos opostos, e portanto também sexuais, parece que fosse muito relevante. Nos dias da comemoração de Yoalúcitl, comprava-se uma mulher e, por alguns dias, ela era tratada como uma grande senhora, dava-se-lhe alimentos saborosos e ela era vestida com ricos ornamentos. Os soldados, com indumentária de guerra, combatiam diante dela para agradá-la. Chegado o dia da festa, ela era morta e esfolada. Um homem de alta posição cobria-se depois com a sua pele e, assim ornado, caminhava por toda a aldeia com os guerreiros e "todos juntos muito se gabavam". (Sahagún 1999:33-34) Que outro modo seria mais explícito para afirmar que a potência feminina deve ser dominada culturalmente pelo homem? $\mathrm{O}$ fato de que a comunidade masculina assuma simbolicamente a identidade da divindade do mundo secreto do parto e da medicina (ato que se desenrola em duas fases: sacrifício simbólico da deusa e sua ressurreição quando o sacerdote veste a sua pele) parece realmente significar que cabe aos homens o controle das potencialidades femininas e a sua conversão em fatos reais. 
«No podemos decir que ya tenemos la merced, sino que nuestro señor nos quiere hacer merced, porque hablamos de cosa muy oscura como el infierno. Que podemos decir determinadamente? Esperemos en aquel por quien vivimos, esperemos lo que sucederá adelante, esperemos en lo que está determinado en el cielo y en el infierno, desde antes del principio del mundo» (Sahagún 1999: 376).

Detenhamo-nos, antes de concluir, em duas ações rituais, o corte do cordão umbilical e o seu enterro.

Superado o momento do parto, dissolvia-se a incerteza da hora da morte e a comadrona agradecia à dupla Ometecuhtli-Omecihuatl por terem desejado que se formasse uma nova criatura, e a Quetzalcoatll por tê-la colocado no ventre da mulher. Rendia-se homenagem, então, ao valor da parturiente, comparada, em seu esforço de "guerreira com o escudo e a espada”, a Cihuacóatl Quilaztli, também chamada "Nossa Mãe Guerreira".17

Conforme o sexo do recém-nascido, o cordão umbilical, naquele tempo como hoje, era enterrado em duas áreas distintas: se era um menino, o cordão era enterrado pelos guerreiros no campo de batalha; se era menina, enterrava-se em casa, mostrando que, para a mulher, aquele teria sido o âmbito social.

Vejamos mais de perto as ações e as implicações simbólicas ligadas a estes dois ritos.

A comadrona, enquanto cortava o cordão ao menino, lembrava-lhe que o seu futuro dever era o de nutrir, com o sangue e o corpo dos inimigos, o sol e a terra, ou seja Tlaltecuhtli. ${ }^{18}$ Além disso, acrescentava:

(17) Na Leyenda de los soles, Chiuacóatl Quilaztli é a divindade que, junto a Quetzalcoatl, dá origem à humanidade. Ela de fato tritura os ossos dos homens, resgatados do inframundo à superfície por Quetzalcoatl, a fim de que este o irrigue com o sangue do seu membro viril. Esta deusa, que Sahagún diz que é a principal divindade adorada na Nova Espanha, era representada com o rosto pintado metade de vermelho e metade de preto, era adornada com um diadema e um colar de crânios humanos.

(18) Tlaltecuhtli, divindade dual masculina e feminina, era a terra que devorava o sol quando este entrava no mundo subterrâneo, até que Coatlique, deusa da terra, o gerasse de
"Y esto que te corto de tu cuerpo, y de (en) medio de tu barriga, es cosa suya, es cosa debida a Tlaltecuhtli, que es la tierra y el sol (...); enterrarla han en medio del campo donde se dan las batallas, y esto es la señal que eres ofrecido y prometido al sol y a la tierra, esta es la señal que tú haces profesión de hacer este oficio de guerra (...); esta es la ofrenda de espina y de maguey, y de caña de humo, y de ramos de acxóyatl, la cual se corta de tu cuerpo, cosa muy preciosa; con esta ofrenda se confirma tu penitencia y tu voto» (Sahagún 1999: 385).

Como já vimos, o maguey e la caña de humo eram os elementos, junto a unhas e cabelos, que aludiam simbolicamente "à vontade dos defuntos de tornar a nascer”. Portanto, parecenos que a oferta do cordão a Tlaltecuhtli possa ser interpretada como o primeiro sacrifício da criança, sacrifício que assume metaforicamente dois significados: por um lado, estabelecer a conexão homem/sol/terra com base na principal atividade culturalmente confiada aos homens e que lhes qualifica a identidade, isto é, a guerra/sacrifício; por outro lado, instituir a correlação simbólica entre auto-sacrificio (corte do cordão) e nascimentos futuros de novas gerações. $\mathrm{O}$ cordão (assimilado ao espinho de maguey) è "restituído" a Tlaltecuhtli, potência da

novo. Tlaltecuhtli, como senhor da terra, recebia em sacrifício os corpos e o sangue dos defuntos para que a sua fome se aplacasse. Esta divindade era também associada às águas universais, chamadas Tlaltecuhtli, sobre as quais flutuava a terra.

$\mathrm{Na}$ Historia de Mexico, a terra, com todos os seus frutos, isto é, flores, árvores, campos, fontes, cavernas, vales e montanhas, nasceu do desmembramento de Tlaltecuhtli por obra de Quetzalcoatl e Tezcatlipoca. Da parte superior da deusa, cortada ao meio, as duas divindades criaram a terra, enquanto que a parte restante foi feita ascender ao céu. Os outros deuses, confusos pelo que tinha acontecido, consolaram-na determinando que, das partes do seu corpo, saíssem todos os bens necessários à vida do homem.

Assim, poder-se-ia perceber Tlaltecuhtli em termos de uma divindade associada à liminaridade: de fato, ela representa a passagem entre o dia e a treva (expressado na idéia da terra que devora o sol) e é associada ao elemento (água cósmica) que separa os dois níveis do universo, terra e mundo subterrâneo. 
qual, em tempos míticos, se teriam originado os bens necessários à vida humana e à qual, ao término de cada existência humana, irão a carne e o sangue dos defuntos, para que "a vontade dos antepassados faça com que germine uma nova vida".

Se o recém-nascido era de sexo feminino, a questão era mais simples: o cordão era enterrado em casa e dizia-se que os deveres da futura mulher, isto é, cozinhar, tecer roupas, acender o fogo e abastecer a casa de água, eram funções que naquele âmbito deviam-se resolver.

Desejamos concluir esta análise dos rituais que acompanhavam o nascimento lançando um olhar à cerimônia da purificação, cerimônia esta que foi logo adotada pelos evangelizadores cristãos e modelada sobre o rito batismal. Uma vez enterrado o cordão, a comadrona, voltada para o oeste, aspergia com água a cabeça da criança, a lavava e fazia entrar algumas gotas deste líquido puro na sua boca. Com estas ações, dizia-se que a criança devia reunir-se a Chalchiuhtlicue, ${ }^{19}$ divindade das águas. Esta destruiria toda a impureza que a criança trazia consigo e que, em parte, derivava dos seus pais.

As ações que se seguem dizem respeito à criança de sexo masculino, que também neste caso era objeto de um complexo de ritos mais articulados. Com ambas as mãos, a comadrona elevava a criança ao céu e depois a depunha no chão, ação que repetia três vezes; na quarta vez, oferecia o menino ao sol, invocado nas suas múltiplas definições - que provavelmente qualificavam-lhe os diferentes atributos. Nesta ocasião, a comadrona confirmava o dever futuro do menino (isto é, de guerreiro) e recordava-lhe o seu destino post mortem, que era o de servir o Sol em sua casa do céu a oriente. Isto feito, a

(19) Chalchiuhtlicue era ligada a Tlaloc, deus de todas as águas correntes, divindade, junto àquela do fogo, entre as mais antigas. Pela importância de que era revestida no panteão asteca, esta deusa das nascentes, dos rios, dos lagos e do mar, era associada ao jade (de fato, era também denominada "Aquela que usa vestes de jade"), o bem mais precioso nesta cultura. $\mathrm{O}$ jade, por sua vez, era associado também ao sangue e, portanto, a deusa era intimamente ligada aos dois "líquidos preciosos", água e sangue. comadrona dava nome ao menino, escolhendo-o entre aqueles de seus parentes defuntos.

Paralelamente a esta ação ritual, desenvolvia-se outro ato importante: enquanto a comadrona purificava o recém-nascido, os jovens da aldeia reuniam-se para preparar uma comida especial denominada "umbigo da criança". Quando tudo estava pronto, eles se uniam aos guerreiros e junto destes, correndo pelas ruas da aldeia, gritavam o nome da criança, recordando-lhe mais uma vez que o menino teria que tornar-se um soldado cujo dever seria alimentar o sol e a terra. Isto feito, repartiam e enfim comiam a comida preparada, isto é, o "umbigo da criança". Com esta ação, concluiase o rito.

Para o recém-nascido de sexo feminino, as coisas eram bem mais simples, ou ao menos assim aparecem nas narrações de Sahagún. Purificada com a água que representava a divindade Chalchiuhtlicue numa cerimônia semelhante àquela efetuada para o menino, também a menina, classificada no papel social que no futuro lhe caberia, vinha associada a uma divindade. Como era de se esperar, esta divindade não era a mesma à qual era associado o menino, o Sol, mas a dualidade Yoaltucitl, Yoatecuhtli "mãe e pai que reside acima dos nove céus", "Senhor da noite", deusa da medicina e do temazcal. A cerimônia terminava com um banquete, mas na descrição de Sahagún não há outros detalhes.

Na sequência de ações cerimoniais descritas acima, temos bem claramente expressas todas as fases de um rito de passagem voltado a transformar o recém-nascido em "ser humano", conforme a imagem elaborada por esta cultura e com base nos próprios valores e concepções do mundo. Vejamos brevemente estas ações em relação à criança de sexo masculino, visto que são descritas de maneira mais meticulosa.

O menino nasce no temazcal, lugar que constitui o ponto de conjunção com os diversos níveis do cosmos e, como por ocasião do parto, o teatro da "guerra" com o mundo subterrâneo, da qual a protagonista é a mãe, e "tem origem 
na união da vontade dos deuses celestes com o desejo dos mortos de voltarem à vida". A criança, de fato, é concebida como aquele que prolonga a realidade dos pais e dos outros parentes defuntos, transferindo-a ao nível da própria geração. No texto diz-se que ele conservará "seu nome" e "sua imagem". ${ }^{20}$

O seu nascimento é, portanto, caracterizado pela impureza: não somente aquela derivada da mãe (ser "por natureza" impuro, enquanto sujeito que, por excelência, é o mediador entre mortos e vivos, através de um contato físico tão estreito que chega a manifestar-se com evidência no seu próprio corpo), mas também aquela impureza que traz consigo do mundo dos mortos, de onde provém. A criança, assim como a mãe, deve, portanto, viver em uma

(20) É relevante esclarecer que com esta interpretação não se pretende dizer que os Astecas acreditassem na reencarnação. Em Sahagún, como também em vários mitos desta área, o Mictlan era descrito em termos claros de lugar de não-retorno. Mesmo nas páginas dedicadas ao nascimento encontram-se palavras que não deixam espaço a dúvidas sobre a irreversibilisade da morte (Sahagún 1999: 396 e 371). Entretanto, a dissolução do que tinha sido a individualidade do ser humano não necessariamente significa a destruição de todas as suas componentes.

A propósito do destino post mortem, Sahagún escreve que os defuntos, depois de quatro anos de peripécias no inframundo, atingiam o Chiconaumictlan e ali, literalmente, "se acababan y fenecían" (Sahagún 1999: 207). Outras fontes contemporâneas a esta obra, por sua vez, nos dizem que os nativos acreditavam na imortalidade da alma e que atingir o último estrato do mundo subterrâneo coincidia com o

"repouso" e o "olvido" do defunto.

As concepções post mortem pré-hispânicas eram bastante complexas, mesmo porque a tipologia do destino ultraterreno variava em função do modo em que tinha morrido o indivíduo, além de depender do período histórico de cada cultura e talvez também do status social do defunto. Dado que sobre este assunto não foram escritas, pelos cronistas da época, descrições detalhadas e de igual conteúdo, os americanistas têm, a esse respeito, idéias discordantes. Não estamos, portanto, em condições de esclarecer em quê consistisse o "desejo dos defuntos de voltar à vida" e se "a imagem" ou o "nome" do defunto que o recém-nascido, dizia-se, trouxesse consigo subentendia alguma substância.

No modelo cultural mesoamericano, onde a morte era o fundamento do renascimento (lembre-se o sacrifício) e onde o movimento contínuo entre princípios antagónicos era o mecanismo que garantia a existência do cosmo (lembre-o sol), torna-se difícil acreditar que a morte humana coincidisse com a desintegração total da vida. condição de separação, que se concretiza num período de reclusão e isolamento.

A cerimônia do corte do cordão umbilical (centro do corpo humano e representação simbólica do eixo de conjunção entre as diversas esferas do cosmos) rompe simbolicamente a ligação entre a criança e as entidades que consentiram no nascimento (mãe impura, reino dos mortos, esfera celeste); a sua oferta a Tlaltecuhtli, divindade ctônica da liminaridade da qual, conforme o mito, provêm os bens necessários à existência humana e à qual irão as substâncias corporais do homem depois da sua morte, marca ainda mais claramente a separação do elemento subterrâneo, ato necessário para a aquisição de uma nova identidade cultural no mundo dos vivos. Por fim, com o corte e o sepultamento do cordão, com a sua valência de primeiro-sacrifício, restitui-se parte do que foi subtraído (ou capturado) ao seu legitimo proprietário extra-humano e, ao mesmo tempo, garante-se o pressuposto de futuros nascimentos.

A fase de transição entre o mundo extrahumano e o mundo humano, do qual o recémnascido deve vir a fazer parte, resolve-se enfim no rito de consumação do umbigo da criança por parte do grupo social que representa paradigmaticamente a sua nova identidade, isto é, os guerreiros. Assim é estabelecida a filiação do recém-nascido, uma vez purificado (ou "dessacralizado"), ao mundo social com o qual compartilhará a sua nova identidade cultural, isto é, os guerreiros. Em outras palavras, nesta ação assimilada simbolicamente a uma refeição canibalesca, os homens, "absorvendo” a criança, subtraem-na definitivamente ao mundo das entidades transcendentes que a tinham feito germinar para englobá-la totalmente no mundo cultural masculino dos vivos.

\section{O temazcal entre "baño de vapor" e "baño de cocimiento"}

No mundo mesoamericano, parece-nos que cada ato cosmogônico importante derivava de uma oposição entre contrários: na mitologia Maia-Quiché (Popol Vuh), o segundo casal de 
gêmeos transforma-se em Sol e Lua após um conflito com os Senhores do mundo subterrâneo; nos mitos do Planalto Central (Leyenda de los Soles), a humanidade se origina dos ossos resgatados ao inframundo e trazidos à superfície por Quetzalcoatl e ainda na mitologia mexicana (Historia de Mexico), os bens da terra tornam-se disponíveis aos homens a partir do desmembramento do monstro ctônico Tlaltecuhtli por obra de dois deuses pertencentes à esfera celeste. Abrindo um parêntese, pode-se dizer que cada um destes atos cosmogônicos funda-se no sacrifício: os dois gêmeos transformam-se em dois astros depois de dar-se a morte no fogo; Quetzalcoatl dá vida aos ossos da humanidade extraindo sangue do próprio membro viril; a deusa Tlaltecuhtli dá origem aos bens indispensáveis à vida do homem com as partes de seu corpo desmembrado. De seus cabelos nascem, de fato, árvores, flores e campos; de suas narinas vales e montanhas; de sua boca, rios e grandes cavernas; de seus olhos, poços e fontes. Paralelamente, pode-se notar que, se para as divindades masculinas o sacrifício é uma ação ativa e conscientemente decidida, para as divindades femininas, ao contrário, parecem ter um papel passivo. Esta distinção já tinha aparecido quando tratamos do diferente destino post mortem das mulheres mortas de parto e dos guerreiros.

No pensamento antigo, os atos cosmogônicos não eram definitivos ou livres de reiteração: de fato, em todas as culturas da área mesoamericana acreditava-se que o universo e a humanidade tivessem sido criados e destruídos várias vezes. A oposição entre polos contrários repetia-se constantemente; era o que consentia o movimento e, assim, a alternância entre dia e noite, estação das chuvas e da seca, vida e morte. A própria ambiguidade que caracterizava cada divindade indicava a multiplicidade inerente a todas as coisas: o Sol, máxima fonte de luz e calor, era também o temível jaguar em sua veste de sol noturno; a Terra, fonte de todos os bens necessários à vida, era também o monstro que constantemente devorava o Sol e que precisava do sangue e do corpo dos defuntos para produzir os seus frutos. $\mathrm{O}$ mundo subterrâneo dos mortos, assimilado pelos cristãos ao
Inferno, era a sede que consentia a germinação da planta sagrada do milho e, assim nos parece, também a fecundação das gerações humanas. Além do mais, o mundo subterrâneo era também considerado o céu noturno e, diziam "los antiguos que cuando comienza la noche comenzaba a amanecer en el infierno, y entonces despertaban y se levantaban de dormir los muertos que están en el infierno" (Sahagún 1999: 381).

Ao considerar, no contexto asteca, os rituais ligados ao parto, assim como aqueles relativos à cura de doenças, a análise históricoreligiosa não nos leva a nenhuma conclusão que confirme a existência de concepções relativas ao estado de saúde e enfermidade com base no binômio quente-frio utilizado pelas populações guatemaltecas de hoje para explicar a doença e a sua cura. Pelo contrário, o pensamento desta cultura antes da Conquista, o seu panteão, os seus rituais, as suas terapias médicas, parecem bem mais complexos do que uma oposição entre as categorias quente e frio. Em relação ao evento do parto, no passado entravam em campo divindades da esfera celeste, mas também, e com importância mais decisiva, aquelas do mundo obscuro subjacentes à vida. A nova criatura era um rebento que devia ser subtraído ao mundo subterrâneo e feito emergir à luz. O teatro desta batalha, da qual a mulher era a protagonista, era o temazcal.

O recém-nascido, todavia, não podia ser concebido como emanação tout court do mundo subterrâneo: para poder vir a fazer parte da sociedade, o recém-chegado devia necessariamente ser "recriado", isto é, transformado culturalmente em um indivíduo com identidade definida. Vimos anteriormente que o corte do cordão umbilical representava a separação dos níveis extra-humanos que tinham consentido o nascimento; a ingestão do "umbigo da criança" significava, por sua vez, a integração do recém-nascido na comunidade dos homens, ou seja, dos guerreiros; a amputação e o enterramento do cordão umbilical fundavam, enfim, a nova relação com as esferas extra-humanas, relação que, daí por diante, seria baseada no sacrifício. Agora, porém, é oportuno interrogar-se sobre o ritual que concretizava a transformação simbólica do 
novo ser capturado ao reino dos mortos em um novo indivíduo a ser integrado à esfera dos vivos.

Uma vez que era o temazcal o lugar onde se concretizava a conjunção com o reino dos mortos, pareceria lícito supor que fossem justamente os elementos fundamentais que nele predominavam a sublinhar simbolicamente também esta passagem.

Assim como na mitologia maia os dois gêmeos atiram-se à fogueira e, depois, na água, para adquirir uma nova identidade (Popol Vuh), nos mitos do Planalto Central, Quetzalcoatl imola-se na fogueira para se transformar na estrela Vênus (códices do grupo Borgia), Nanáhuatl e Teccizteécatl saltam no braseiro para transformar-se em Sol e Lua (Leyenda de los soles), ${ }^{21}$ parece-nos verossímil que a nova criatura saída do ventre da mãe fosse "transformada" simbolicamente em indivíduo humano pelo elemento que paradigmaticamente aludia à mediação entre termos diversos, pressuposto indispensável à transição para um novo estado: o fogo.

Para compreender melhor o significado que tinha no passado o "banho de vapor", parece portanto necessário concentrar-se, ainda que de forma breve, nos dois elementos fundamentais que liberam vapor, justamente o fogo e a água.

Entre os povos da Mesoamérica, era difusa a idéia de que o Fogo fosse o "deus Velho", o "Pai de todos os outros deuses". Acreditava-se que vivesse no umbigo da terra, isto é, nas vísceras profundas dos vulcões, mas também nas divindades celestes, especialmente no sol. O fogo constituía, portanto, o eixo do cosmos que colocava em conjunção o mundo do subsolo, portanto dos mortos, e a esfera sobrejacente da luminosidade e também da vida. O fogo era também o "Senhor da proximidade", quer dizer, do presente imediato, uma vez que vivia em todas as casas sob a forma de fogo doméstico.

(21) O tema da transformação através do fogo se encontra também na Leyenda de los soles e na Historia de los Mexicanos por sus pinturas, donde Lua e Sol origirinam-se da morte no fogo.
O fogo é o elemento transformador por definição: era indispensável para converter os elementos da natureza em comida (lembre-se que o milho, a planta sagrada ao ponto de constituir a carne do homem, não é comestível quando crua), a resina preciosa do copal em perfumada oferta aos deuses, o frio em calor, as trevas em luz. O fogo era também o principal instrumento da atividade agrícola, baseada no sistema de "derrubada e queima" (slash and burn), utilizado não somente para o desmatamento, mas também como fertilizante do terreno. No pensamento destas populações, o fogo representava, portanto, uma passagem do estado de natureza ao de cultura.

Para os Astecas, o Deus do Fogo Xiuhtecuhtli, substituindo o ancestral deus Huehuetéotl, era importante a ponto de ser representado sobre a terra pelo soberano, encarnação do Sol que tinha dado início à quinta era cósmica. Ele era, portanto, o centro do universo e o fiador da ordem cósmica. Lembre-se, além disso, que a festa mais importante para os Astecas era aquela denominada "o Fogo Novo", com a qual era celebrado o fim de um ciclo de 52 anos, comparável ao nosso século. A cerimônia mais importante da festa comemorava o "século morto" e celebrava a "renovação do fogo". Nos cinco dias funestos que marcavam esta delicada transição, eram apagados todos os fogos dos templos, dos palácios e das casas; no meio da quinta noite, observando o momento em que as Plêiades atingiam o zênite, os sacerdotes acendiam um novo fogo no coração de um prisioneiro sacrificado, ato preliminar ao acendimento dos braseiros de todas as lareiras e à inauguração do novo século. $\mathrm{O}$ desaparecimento do fogo durante os cinco dias de passagem ao novo século coincidia com a supressão de qualquer forma de cultura: a comunicação entre homens e deuses era interrompida. Com o acendimento do fogo através do sacrifício recompunha-se, enfim, a correta conjunção entre plano celeste e plano terrestre e, com esta, as múltiplas relações que constituíam a trama do cosmos.

É digno de nota, além do mais, o fato de que, para algumas populações do vale do México, as divindades femininas representantes 
do fogo subterrâneo e do "fogo na casa" (Chantico e Itzpapálotl) fossem retratadas com facas de obsidiana, encarnação dos espíritos das mulheres mortas no parto que desciam do céu noturno. Às vezes, porém, elas se confundiam com divindades femininas da terra, com as quais compartilhavam emblemas e características. $\mathrm{O}$ exemplo mais relevante é o de Cihuacóatl, "Velha Princesa", complemento do velho deus do fogo, chamada também "Nossa Mãe Guerreira".

Assim, as deusas do fogo eram, simultaneamente, divindades estelares, associadas à noite, e divindades associadas ao subsolo (Krickeberg 1995: 142). Em ambos os casos, tanto enquanto estrelas, quanto como fogo doméstico, exprimiam uma mediação com as trevas e, portanto, com a morte.

Enquanto o soberano asteca encarnava o deus do fogo sobre a terra, o seu suplente, o coregente assumia o nome de cihuacóatl ("serpente-fêmea"), personificando a antiga deusa da terra que, como vimos, era associada também às estrelas (manifestação noturna do fogo), à noite, à morte.

No emaranhado de cerimoniais estreitamente ligados à mitologia, a interseção entre vários sistemas simbólicos, cada um deles com um diverso nível de significados, produz sistemas que compartilham a mesma lógica interna. O fogo representava o centro do universo, da casa e do império asteca, mas era também relacionado à morte, à transformação em uma nova condição e a uma nova era temporal, à vida e ao parto. Mesmo na representação do mais arcaico deus Huehuetéotl, descoberta no Templo Maior da Cidade do México, encontram-se símbolos ligados não só ao fogo, mas à água, ao inframundo, à morte.

Vejamos agora o que se pode deduzir do passado acerca da água. As divindades da água, junto àquelas ancestrais do fogo, estão entre as mais antigas e acreditava-se que governassem não somente as águas subterrâneas e de superfície, mas também o desenvolvimento de todas as plantas alimentares. Em diversos relatos cosmogônicos mesoamericanos narravase, inclusive, que a terra se apoiasse sobre as águas cósmicas que a circundavam e separavam do mundo subterrâneo.
Chalchiuhtlique, divindade da água invocada no rito de batismo no temazcal, era a consorte, ou em outros casos a irmã, do principal deus das águas, Tlaloc ("aquele que faz crescer"), e era ao mesmo tempo divindade da água e do milho. O mês do ano a ela dedicado (Etzalcualiztli) coincidia com o início da estação das chuvas e, portanto, da semeadura da preciosa planta comestível que era também a essência do homem. Chalchiuhtlique era associada, como vimos anteriormente, também ao jade e ao sangue, elementos que por excelência simbolizavam a preciosidade.

Algumas sugestões para compreender melhor a associação "milho-jade-sangue" vêm de um trecho do Chilam Balam, citado por Thompson: neste texto sagrado narra-se que a jovem planta de cor verde brilhante do milho, portanto da mesma cor do jade, estava escondida dentro de uma pedra, na escuridão da noite. Depois, a pedra pulverizou-se e, naquele momento, dela veio à luz a divindade do milho. De outras fontes sabemos também que o milho constituía a carne do homem (Thompson 1995: 324).22

Estas informações, ainda que contidas em um texto maia do século XVI, sugerem novos elementos para compreender a conexão jademilho-sangue (essência mais preciosa do ser humano). Interrogamo-nos, abrindo mais um parêntese, sobre se a definição de pedra preciosa que aparece sempre na obra de Sahagún para denominar o recém-nascido não aludisse, portanto, justamente ao jade, isto é, ao milho, e, assim, à essência do homem, ao seu sangue.

Lembre-se, além disso, que os povos mesoamericanos costumavam colocar na boca do morto, sobretudo se de alta extração social, uma pedra de jade, interpretada por alguns estudiosos em termos de óbolo que o morto devia pagar aos senhores do mundo subterrâ-

(22) Numa versão de um mito muito difuso em toda a área mesoamericana, contida no códice Telleriano-Remensis, o deus-Milho surge do sacrifício de Cintéotl, divindade nascida da união entre a deusa Xochiquetzal (identificada em outras versões com Cihuacóatl, dado que também ela tinha morrido dando à luz) e Tezcatlipoca. O fruto desta união, isto é, Cintéotl, foi enterrado e dele germinou a seguir o deus do milho. 
neo para poder atravessar o rio perigoso que por lá passava. Tendo presente este último mito, parece-nos mais apropriado supor que o jade na boca dos defuntos representava o pressuposto de um futuro nascimento: como o milho ciclicamente germina nas profundezas da terra para emergir à luz do sol, assim também o "jade-sangue do homem" aludiria simbolicamente àquele ato pelo qual a pedra preciosa - o jade - teria voltado a se despedaçar e, das suas partes, conjuntas à pluma rica - símbolo da esfera celeste - teria tomado vida uma nova criatura.

Voltando à deusa Chalchiuhtlique, também conhecida como "de jade a sua saia", observe-se que era estreitamente associada ao reino subterrâneo da fertilidade, que permitia o renascimento tanto do milho quanto da pedra preciosa-jade, justamente em virtude de sua essência vital, a água, elemento que mais do que qualquer outro era indispensável à germinação e ao crescimento vegetal.

Chalchiuhtlique estava, além do mais, em relação com a Lua, divindade de certo modo antagonista do Sol (na Historia de los Mexicanos por sus pinturas, Lua é filho desta deusa e de Tlaloc, principal divindade das águas) e era invocada pela comadrona na cerimônia que, por convenção, assim como Sahagún, chamaremos de batismo. Nesta ocasião, a comadrona borrifava gotas de água pura e lavava a criança para purificá-la, consagrando-a a Chalchiuhtlique, «señor del mundo, que es nuestra vida, y es para que nuestro cuerpo crezca y reverdezca, es para lavar, para limpiar». As palavras proferidas pela comadrona neste rito são reveladoras da função atribuída a esta divindade:

"ahora vive de nuevo y nuovamente nace este niño, ahora otra vez se purifica y se limpia, otra vez le forma y engendra nuestra madre Chalchiuhtlique» (Sahagún 1999: 399).

O valor purificador da água ("que lavava as impurezas dos genitores que a criança trazia consigo ao nascer"), enfatizado por Sahagún em numerosos trechos de sua obra, acreditamos fosse, portanto, secundário em relação à sua função regenerativa.
A associação entre água e renascimento, em seu sentido de "re-criação", parece presente também na cultura maia antiga. $\mathrm{O}$ rito que Landa assimilou ao batismo era, de fato, denominado "nascer de novo ou nascer outra vez" e a deusa Ix Chel, protetora do parto e consorte do deus supremo Izamna, era estreitamente associada à lua e à água, além de ser a padroeira da medicina e da feitiçaria (Landa 1986: 44).

Se percorrermos os cinco dicionários do idioma maia yucateco escritos durante a Conquista, encontraremos que "parir" dizia-se "vaciar agua de alguna vasija" (hoch hal), enquanto que "arrojar agua" (ch'in ha) denominava a cura praticada pelos curanderos no banho que "davam nos doentes para que suassem e que se realizava colocando-os perto de uma pedra muito quente". Nestes mesmos dicionários, traduzia-se "llamar fuego" com "provocar a própria morte e a própria destruição”, enquanto que "contraer fuego" era traduzido como "adoecer" (Alvarez 1984: 315 e 365). Note-se, além disso, que as doenças pelas quais o fogo era responsável eram o sarampo, a varíola e, mais em geral, todas as enfermidades contagiosas que se manifestavam com alterações na pele, como chagas, úlceras, verrugas. ${ }^{23}$ Levando-se portanto em consideração o fato de que o fogo era também usado para iniciar novas atividades e para a inauguração dos meses do ano em que o calendário maia antigamente se estruturava, parece que, assim como entre os Astecas,

(23) No mito de origem de Sol e Lua, contido na Leyenda de los soles, acima mencionado, narra-se como Nanáhuatl, dito também "o Ulceroso", se atirasse no fogo antes da entidade de melhor aspecto, mas mais hesitante, Teccizteécatl, que a seguir, vencida a sua relutância, se tornará Lua, a antagonista do sol, aquela que o segue sempre sem poder alcançá-lo. A morfologia do herói cultural que se tornará o sol é, neste mito, indubitavelmente marcada pelos "bubões" que lhe cobrem o corpo: sobre isso nada se acrescenta, a não ser que foi mais destemido que seu companheiro ao jogar-se no fogo. Aqui seria suficiente notar que na Leyenda de los soles, o sol, máxima expressão celeste do fogo, é estreitamente associado às mutações visíveis do corpo, fato que provavelmente relembrava, em um outro nível de significado, a sua associação ao motivo da transformação. 
também entre os Maias o fogo era associado ao significado de morte-transformação, enquanto que a água desvelava a acepção de saneamentonascimento- regeneração.

Entre as prerrogativas simbólicas atribuídas no passado a estas duas entidades, fogo e água, parece-nos possível encontrar uma resposta satisfatória à pergunta que nos tínhamos colocado: quais eram os elementos rituais que deviam necessariamente intervir para marcar metaforicamente a passagem da nova criatura do mundo dos mortos ao dos vivos? O fogo era o centro do cosmos em que se realizava uma conjunção entre polos distantes entre si, fato que permitia uma transformação. A água, potência subterrânea, mas também de superfície, era o elemento que, favorecendo a germinação ou a saída do ventre da terra de todo o mundo vegetal e, antes de mais nada, do milho, remetia metaforicamente à geração também do ser humano. Este processo contínuo, vale a pena repetir, acontecia sempre através de um conflito e não era uma alternância predeterminada em um projeto cósmico de equilíbrio. Não por acaso, nas pictografias, o glifo águafogo (atl-tlachinolli) representava o conceito da união dos contrários e da guerra sagrada que mantinha em função a máquina do mundo.

O calor produzido no temazcal, o "banho de vapor", parece então que fosse de importância marginal em relação ao significado atribuído ao vapor liberado pela conjunção de fogo e água. Lembre-se que à comadrona, na descrição de Sahagún, preocupava somente que a temperatura no temazcal não fosse tal que pudesse prejudicar a saúde da mãe e da criança, que poderia "queimar-se". Naquela longa descrição, nunca se acenava às qualidades terapêuticas do calor, tanto em termos físicos, quanto em termos metafóricos.

Desejamos concluir esta discussão sobre o temazcal com algumas notas de caráter histórico.

Acenamos anteriormente ao fato de que o temazcal fosse hostilizado pelos evangelizadores, porque considerado lugar em que se perpetravam ações ilícitas, contrárias à religião cristã, que se distinguiam por idolatria e, como se não bastasse, promiscuidade sexual. Em linhas gerais, pode-se dizer que, até a introdução oficial da Inquisição na Nova Espanha (1571), sobre o temazcal havia opiniões divergentes: de um lado, havia quem o defendesse apelando-se ao seu valor terapêutico, de outro, alinhavam-se seus adversários, convictos de que naquele lugar se consumassem ritos mágicos e relações sexuais, inclusive a sodomia.

A opinião sobre a Nova Espanha era contraditória já desde os primeiros passos dos espanhóis sobre este solo e discordante era também o juízo sobre o temazcal, assim como sobre outros elementos da cultura mesoamericana que, para alguns, deviam ser extirpados e, para outros, civilizados. Sintetizando os dados de estudos históricos sobre o temazcal realizados por Alejandro Tonatiuh Romeros Contreras (Romeros Contreras 2001: 133-144), Natalia Silva Prada (Silva Prada 2002: 5-56), Alcina Franch (Alcina Franch 2000) e Lillo Macina (Lillo Macina 2007) pode-se dizer que, nas primeiras décadas que seguiram à empresa de Cortés, houve quem reconhecesse no temazcal uma finalidade terapêutica. Um temazcal foi inclusive anexado ao hospital de Tiripitío em Michoacan em 1543 e, poucos anos depois, foi construído um outro junto ao Hospital Real de los Naturales (1534). Em 1552 foi também enviado da Espanha um funcionário com a tarefa de estudar e classificar as plantas medicinais utilizadas nesta estrutura (Martin de la Cruz, autor do Códice badiano).

Com a subida ao trono da Espanha de Felipe II, convicto artífice da política de hispanização das terras de além-mar, o aparato da Coroa e da Igreja instalou-se solidamente também nas colônias. Em relação ao temazcal, prevaleceu a opinião de quem estava mais preocupado com seus aspectos muito pouco médicos, isto é, dos encontros ilícitos e das libações de pulque que ali se consumavam. Com o edital "Las ordenanzas del siglo XVI", todos os temazcales são proibidos e fechados. Todavia, apesar dessas medidas, o uso do temazcal nunca desapareceu completamente.

Para quê se recorria ao temazcal no século imediatamente posterior à Conquista, e não obstante a sua proibição, não é possível saber com certeza, dada a escassez e fragmentariedade 
das informações. O que é certo é que, em 1689 , ocorreu uma grande mudança histórica que reabilitou o temazcal para fins higiênicos e, mais genericamente, para fins terapêuticos. Esta mudança foi desencadeada pelo relatório de dois dos médicos mais respeitados da época: Ambrosio de la Lima y Escalada e Joseph de Oliver. Solicitado pelo Vice-rei de então um parecer respeitável sobre o assunto, os dois médicos redigiram um relatório em defesa do temazcal, argumentando que a água tinha propriedades fortificantes, necessárias a reforçar os homens e conservá-los em saúde. Estes enfatizavam, além disso, que a sudoração era benéfica, uma vez que ajudava a expelir os maus humores. O doutor Oliver escreveu, inclusive, que os temazcales, comparados às termas romanas e aos banhos alemães, podiam ter resultados benéficos não somente para os indios, mas também para os brancos ou espanhóis. Ele prevenia, também, que para estes últimos, "de temperamento mais ardente, de sangue colérico e mais propenso ao catarro", seria mais salutar um banho d'água, em vez daquele na "estufa".

Ambos os médicos, para defender o uso da água enquanto agente terapêutico, recorreram em várias ocasiões a Hipócrates e a Galeno e, em especial, ao Tratado "Sobre as águas, sobre os ventos e sobre os lugares", parte do Corpus Hippocraticum, no qual evidenciavam-se as ligações entre doença e ambiente e, com base nos ensinamentos da medicina contidos no mesmo, recomendaram o uso da água para todas as enfermidades caracterizadas pelo excesso de calor.

Para compreender plenamente a tomada de posição dos dois respeitados médicos, é necessário ter presente que a primeira epidemia de varíola na Nova Espanha provocou mortes já em 1520; a esta epidemia seguiu-se uma de sarampo (1531) e, poucos anos depois, outras duas, muito violentas, mais uma vez de varíola (1545 e 1576). Entre estas epidemias, alternaram-se outras de tifo, sarampo, varicela, parotidite endêmica (caxumba), gripe A e B, malária, etc. Em resumo, calcula-se que entre 1519, ano da chegada de Cortés, e 1650, a população indígena da Mesoamérica tenha diminuido drasticamente. Um dos fatores principais de despopulação foi de natureza epidemiológica (Livi Bacci 2005)

Os dois médicos encarregados de exprimir um parecer que pusesse fim a todas as controvérsias que giravam em torno ao temazcal chamaram a atenção para o fato de que os indios que sucumbiram às epidemias representavam a população mais pobre, aquela que vivia em condições de insalubridade, em meio à sujeira e cuja alimentação era insuficiente. Concluíram, então, seu relatório ao Vice-rei Gaspar Sandoval Silva y Mendoza, Conde de Galve, escrevendo que seria provocado um grande dano à saúde dos indios se fossem eliminados também os temazcales, no mínimo porque, no temazcal, mesmo os mais indigentes, privados de recursos econômicos e de alternativas médicas, teriam a possibilidade de limpar o corpo. Levando em consideração as luzes da ciência da época, os dois médicos explicaram que os índios possuiam os poros da pele menos dilatados do que a população espanhola e que, portanto, o banho quente era para eles mais adequado, uma vez que podia favorecer a expulsão dos "humores perversos de que estavam cheios".

Esta última declaração científica nos leva a constatar que até mesmo para a Colônia tinha sido exportada a medicina dos quatro humores corporais de Hipócrates e Galeno. Note-se ainda que o temazcal é denominado pelos dois médicos "estufa", termo que nunca tinha aparecido na longa obra descritiva de Sahagún.

Vejamos agora como concluiu-se a questão temazcal.

Após o relatório dos dois médicos de 1689 , o temazcal foi usado oficialmente pelos próprios espanhóis para fins higiênicos e terapêuticos e foi aceito pelo Vice-rei, que, entretanto, impôs algumas restrições, tanto em relação ao número de temazcales como à sua utilização. Mais tarde, com a "nueva Reglamentación de los Temazcales publicos para la Ciudad de Mexico" (1793) reduziu-se definitivamente o número de temazcales da capital mexicana e foram estabelecidas normas para a sua arquitetura e funcionamento. Naquele período, começou-se também a investigar o uso do temazcal para a 
rentável produção da tintura obtida da cochonilha e pesquisou-se a quantidade de calor que devia ser atingida pelo temazcal para fazer com que todos os insetos morressem. Entretanto, à parte este interesse puramente econômico, o temazcal atraiu a atenção de estudiosos do século XIX, sobretudo pelo uso das plantas que nele se fazia. Dois frades franciscanos, em 1881 e em 1888 , tentaram uma catalogação das plantas medicinais utilizadas no banho de vapor, associando o seu nome indígena à nomenclatura científica com base na classificação de Lineu. Nos poucos escritos produzidos sobre o temazcal no Século das Luzes, desaparece definitivamente qualquer referência à idolatria, diminui o interesse em descobrir conexões com o mundo diabólico dos malefícios e da magia e concentra-se a atenção mais sobre os aspectos pragmáticos voltados ao restabelecimento da saúde.

A trajetória histórica do temazcal conclui-se nos nossos dias com os movimentos de revivificação da cultura indígena.

No México, além da cura de enfermidades tradicionalmente classificadas como "frias", entre as quais o parto, vários movimentos indígenas retomam esta instituição cultural em termos de "lugar ancestral no qual experimentar o contato místico com a Mãe Terra e a sabedoria antiga dos xamãs"; exalta-se, além disso, a experiência das propriedades extrasensoriais contidas nas "plantas sagradas" administradas no temazcal e a absorção de "energia e boas vibrações” por elas liberadas. A entrada no temazcal torna-se um contato místico com a Mãe Terra, que qualquer um pode experimentar, desde que se ponha nas mãos de sábios guias espirituais, frequentemente denominados "xamãs". O trabalho mexicano considerado como o mais representativo desta nova tendência é: "Temazcalli, medicina tradicional indígena chamánica”, (Olivares Martínez 1999). No México, o temazcal chegou, assim, também a uma parte, ainda que, como a exotérica, restrita, do mundo turístico. Quem quer que procure em internet, encontrará uma enorme variedade de ofertas voltadas a satisfazer qualquer tipo de exigência ou curiosidade.

$\mathrm{Na}$ Guatemala, ao contrário, menos desenvolvida do ponto de vista turístico, o temazcal ainda é utilizado para o parto, apesar de condenado pelo Ministério da Saúde, segundo o qual o alto índice de mortalidade materna devida a hemorragias pode ser atribuído justamente ao uso, o mais das vezes impróprio, do temazcal. ${ }^{24}$

Concluindo, com a chegada dos espanhóis na Mesoamérica, repentinamente produziramse mudanças dramáticas. O mundo dos deuses, fundado no sacrifício (ato ritual que sequer os frades mais esclarecidos podiam consentir), desmoronou. A população autóctone reduziu-se drasticamente em poucos anos e com isso desapareceram as elites guerreiras e os sacerdotes, isto é, aqueles que detinham o saber e que deviam transmitílo de geração em geração. Além da redução demográfica - que, segundo os dados, foi uma verdadeira dizimação epocal, as epidemias devem ter repercutido dramaticamente também em outro fronte: o da confiança na eficácia e validade da medicina autóctone. Com o ocaso dos velhos deuses, aniquilados pela chegada dos novos, extraordinariamente mais fortes, todas as outras instituições também vacilaram. Mais que todas as outras, a medicina, que se encontrou diante de doenças desconhecidas, contra as quais os antigos deuses, as cerimônias a eles ligadas e as terapias até então experimentadas, demonstravam-se ineficazes. A mortandade de indígenas certamente pôs em crise também as certezas dos sobreviventes em relação ao próprio sistema médico.

Poderia parecer que, mesmo com vários percalços, o temazcal conseguiu sobreviver a este choque extraordinário, mas os seus significados originais mudaram, evoluindo em função das

(24) Esta crítica constitui um ponto-chave da controvérsia e da complexa relação entre o Ministério Público da Saúde Guatemalteco, comadronas, e, mais em geral, os movimentos indigenas maia. Sobre a crítica do Ministério ao temazcal, assim como a outras práticas tradicionais dos terapeutas indígenas, concentra-se o conflito, às vezes realmente áspero, entre quem acredita na necessidade de um reconhecimento e, portanto, de tutela da medicina indígena, guardiã do "saber ancestral maia", e quem, pelo contrário, a este se opõe, não reconhecendo a validade cientifica nem de seus postulados nem de suas práticas. 
novas concepções que se impunham. A repressão a esta instituição e a sua posterior adaptação como lugar de higiene e de expulsão dos maus humores através do calor, transformaram o temazcal de "sede da mãe de todos os deuses", "coração da terra e dos segredos da medicina", em "estufa" e "baño de cocimiento". Parece lógico, então, pensar que foi justamente naquele tempo que o temazcal estigmatizou-se como lugar que produz calor, tout court.

PERETTI, L. The temazcal between past and present. Revista do Museu de Arqueologia e Etnologia, São Paulo, 19: 285-307, 2009.

\begin{abstract}
The present work is part of a reflection on the phenomenon of the Maya Resurgence and, in specific, on its request to integrate traditional medicine with that of official medicine. The work outlines a discussion of the traditional practices of the Guatemalan comadronas during child-birth and attention was primarily focused on the temazcal. Through historical and religious analysis, the meanings this institution represented in Pre-Columbian times were investigated and their evolution through time, if only summarily, were outlined. In a dialectic rapport with the world vision that the Occidental brought, the temazcal changed, according to the results obtained through our analysis, from a theatre of combat with the underworld, to a place where indispensable "heat" was unleashed to warm the mother in childbirth, who during her delivery reaches her maximum state of coldness (Guatemala), or a mystical place in which contact with Mother Earth is experienced (Mexico).
\end{abstract}

Keywords: Temazcal - Comadronas - Child-birth - Binomial hot/cold.

\title{
Bibliografia
}

ACOSTA, J.

1992 Historia natural y moral de las Indias. México: UNAM.

AGUIRRE BELTRÁN, G.

1963 Medicina y Magia: el proceso de aculturación en la estructura colonial. México: INI.

1994 Obra Antropológica XIII, Antropología Medica, Sus desarrollos teóricos en México. México: Fondo de Cultura Económica.

ALCINA FRANCH, J.

1991 Procreación, amor y sexo entre los mexicas. Estudios de cultura Nahuatl, 21. Mexico, UNAM: 59-82.

ANDERS, F.; JANSEN, M.

1996 Religión, Costumbres e Historia de los Antiguos Mexicanos. Libros Explicativos del llamado Códice Vaticano A. Áustria:
Fóndo de Cultura Económica de México e Akademische Druck und Verlagsanstalt.

BENAVENTE, T. de

2001 Historia de los Indios de la Nueva España. Madrid: Dastin.

CODICE CHIMALPOPOCA, ANALES DE

CUAUHTITLAN Y LEYENDA DE LOS SOLES

1975 México: UNAM Istituto de Investigaciones Historicas.

CODICE MENDÓZA

1974 Milano: Garzanti.

DURÁN, D.

1967 Historia de la Indias de Nueva España y de islas de tierra firme. México: Porrúa.

DUVERGER, C.

1981 Il fiore letale. Il sacrificio nella civiltà azteca. Milano: Mondadori.

2004 Cortés. Roma: Salerno. 
FLORESCANO, E.

1999 Memoria indígena. México: Taurus.

2001 Etnia, Estado y Nación. México: Taurus.

FOSTER, G. M.

1987 On the Origin of Humoral Medicine in Latin America. Medical Anthroology Quartely, 1(4), December: 355-393.

GARIBAY, A.M.

1965 Teogonia e historia de los mexicanos: tres opusculos del siglo 16. México: Porrúa.

GARZA de la, M.

1998 Rostros de los Sagrado en el Mundo Maya. México: UNAM Paidós.

GÓMARA, F.L. de.

2001 La Conquista de México. Madrid: Dastin.

GRAÑA BEHERENS, D.

2001 El Juego de pelota Maya. In: Eggebrecht, E. A.; Seipel, W. ( Eds.) Maya Amaq, Mundo Maya. Guatemala, Cholsamaj (Editorial), apoyado por Fondo de Desarrollo Indígena Guatemalteco (FODIGUA): 203-228.

GRAULICH, M.

2006 L'ideologia del sacrificio umano azteco. In: Lupo A.; López Luján, L.; Migliorati L. (Eds.) Gli Aztechi tra passato e presente. Roma, Carrocci: 51-57

GRUZINSKI, S.

2001 La colonización del imaginario. Sociedades indígenas y occidentalización en el México español. Siglos XVI-XVIII. México: Fondo de Cultura Economica.

GÜEMEZ PINETA, M.

2000 La concepción del cuerpo humano, la maternidad y el dolor entre mujeres mayas yucatecas. Revista Mesoamérica, Año 21, 39: 305-333.

HERNÁNDEZ, F.

2000 Antigüedades de la Nueva Espana. Madrid: Dastin.

HURTADO, E.; SÁEZ DE TEJADA, E.

2001 Relation Between Government Health Workers and Traditional Midwives in Guatemala. In: Huber B.R.; Sandstrom A.R. (Eds.) Mesoamerican Healers. Austin: University of Texas Press: 211-242.

KATZ, E.

1993 Recovering after childbirth in the Mixtec Highlands (Mexico). In: ORSTOM (Institut Français de Recherche Scientifique pour le Développement en Coopération), Actes du 2 Colloque d'Ethnopharmacologie et de la 11 Conférence internationale d'Ethnomédecine. Heidelberg: 24-27.
ICHON, A.

1973 La religión de los Totonacas de la Sierra. México: Istituto Nacional Indigenista.

LEÓN PORTILLA, M.

1986 Cantos y crónicas del México antiguo. Madrid : Historia 16.

LÓPEZ AUSTIN, A.

1997 De la racionalidad, de la vida y de la muerte. In: Malvido, E.; Pereira, G.; Tiesler, V. (Eds.) El cuerpo humano y su tratamiento mortuorio. México, INAH e CEMA: 13-17.

LÓPEZ DE GÓMARA, F.

2001 La conquista de México. Madrid: Dastin. OLIVARES MARTINEZ, J.

1999 Temazcalli, medicina tradicional indígena chamánica. México: Ayuntamiento Ciudad de Toluca.

MADSEN, A.

1965 Study of Change in Mexican Folk Medicine. Middle American Research Institute, Tulane University Publication, New Orleans, 25: 89-138.

MAGLI, I.

1982 la femmina dell'uomo. Bari: Laterza.

MATOS MOCTEZUMA, E.

1986 Los dioses que se negaron a morir. México: CEP.

1997 Muerte a filo de Obsidiana. Los nahuas frente a la muerte. México: Fondo de Cultura Económica.

MINISTERIO DE SALUD PUBLICA Y ASISTENCIA SOCIAL.

2006 Agenda Nacional de Salud e Acuerdos de la Mesa de Salud y Nutrición, Guatemala 13 Septiembre 2006.

MONACO, E.; MECCHIA A.

2003 Miti Aztechi e Maya. Roma: Bulzoni. ORTEGA CANTO, J.

2006 Géneros y Generaciones: Conducta Reproductiva de los Mayas de Yucatán, México. Salud Colectiva, Buenos Aires, 2 (1): 75-89.

PONCE, P.

1892 Dioses y Ritos de la Genilidad. México: Imprenta del Museo Nacional.

POPOL VUH, LE ANTICHE STORIE DEL QUICHÉ 1960 Recinos, A. (Ed.). Torino: Einaudi. PRADA NATALIA, S.

2002 El uso de los baños temazcales en la visión de dos médicos novohispanos. Estudio introductorio y transcripción documental de los informes de 1689. In: Historia Mexicana, vol.LII, n. 001, Colégio de México: 5-56. 
RAGOT, N.

2000 Le Chichihualcuahhco, la résurrection et la reinaissance dans la pensée aztèque. Journal de la Société des Américanistes, 86 (1): 49-66.

2000 Les au-delas aztèques. American Archaeology, 7. BAR International Series 881, Paris Monographs.

RIVERA DORADO, M.

2006 El pensamiento religioso de los antiguos mayas. Madrid: Trotta.

RUIZ DE ALARCÓN Y MENDOZA, $\mathrm{H}$.

1952 Tratado de las supersticiones de los naturales de esta Nueva España. In: Tratado de las idolatrias, supersticiones, Dioses, ritos, hechicerias y otras costumbres gentilicas de las razas aborigenes de Mexico. Tomo XX, México, Fuente Cultural: 17. 180.

SÁEZ, H.L.M.; FOSTER, G.M.

2001 Maya Midwives of Southern Mexico and Guatemala. In: Huber B.R.; Sandstrom A.R. (Eds.) Mesoamerican Healers. Austin, University of Texas Press: 19-65.

SANTOS, E.N. dos

2002 Deuses do México indigena. São Paulo: Palas Athena.

SCHELE, L.; FREIDEL, D.

2000 Una Foresta di Re. Milano: Corbaccio. SILVINI, G.

1985 L'impero degli Aztechi nella sua tradizione storica. Il "Codice Ramirez», manoscritto della prima metá del sec. XVI. Milano: Paline.

TALADOIRE, E.

2002 The Architectural Background of the preHispanic Ballgame: an Evolutionary Perspective. In: Whittington, E.M. (Ed.) The Sport of Life and Death. The
Mesoamerican Ballgame. New York, Thames \& Hudson: 96-115.

TEDLOCK, D

1985 Popol Vuh. The Definitive Edition of the Mayan Book of the Dawn of Life and the Glories of Gods and Kings. New York: Simon \& Schuster.

THOMPSON, J.E.

1970 La civiltà Maya. Torino: Einaudi.

TODOROV, T.

1984 La conquista dell'America. Il problema dell'"Altro". Torino: Einaudi.

TODOROV, T.; BAUDOT, G.

1988 Racconti aztechi della Conquista. Torino: Einaudi.

TREVIÑO RIESCA, C.

2001 Curanderismo in Mexico and Guatemala. Its Historical Evolution from the Sixteenth to the Nineteenth Century. In: Huber, B.R.; Sandstrom, A.R. (Eds.) Mesoamerican Healers. Austin, University of Texas Press: 47-65.

VILLA ROJAS, A.

1995 Estudio etnologico: los mayas. México: UNAM.

1990 Etnografia Tzeltal de Chiapas. Modalidades de una cosmovisión prehispánica. México: Porrúa.

VILLATORO, E.M.

2001 Promoción de la Medicina y Terapias Indigenas en la atención primaria de Salud: el caso de los Maya de Guatemala. OPS. Disponivel on line.

VILLATORO, E.M. (Ed.)

2005 Etnomedicina en Guatemala. Ciudad de Guatemala: Universitaria.

VOGT, Z.E.

1976 Ofrendas para los dioses. México: Fondo de Cultura Económica.

\section{Referências bibliográficas}

\section{ALCINA FRANCH, J.}

2000 Temazcalli. Higiene, Terapéutica, Ostetricia y Ritual en el Nuevo Mundo. Sevilla: Escuela de Estudios Hispano-Americanos.

ALCINA FRANCH, J.; CIUDAD RUIZ A.; IGLESIAS PONCE DE LÉON J.I.

1980 El "Temazcal" en Mesoamerica: evolución, forma y función. Revista Española de Antropología Americana. Madrid: Universidad Computense de Madrid, X: 93-132.
ALVAREZ, C.,

1984 Diccionario etnolinguistico del idioma maya yucateco colonial. México: UNAM.

\section{COSMINSKY, S.}

2001 Maya Midwives of Southern Mexico and Guatemala. In: Huber, B.R.; Sandstrom A.R. (Eds.) Mesoamerican Healers. Austin, University of Texas Press: 179-210. 
FLORESCANO, E.

1995 El mito de Quetzalcoatl. México: Fondo de Cultura Economica.

FOSTER M. G.

1994 Hippocrates' Latin America Legacy. Humoral Medicine in the New World. Berkeley: University of California, Gordon and Breach.

GRAULICH, M.

1988 Quetzalcoatl y el Espejismo de Tollan. Anversa: Instituut voor Amerikanistiek.

1990 Mitos y Rituales del Mexico Antiguo. Madrid: Istmo.

HURTADO, E.

2005 Estudio de las características y prácticas de las comadronas tradicionales en una comunidad indígena de Guatemala. In: Villatoro, E.M. (Ed.) Etnomedicina en Guatemala. Ciudad de Guatemala: Universitária: 235-247.

KRICKEBERG, W.

1995 Las Antiguas culturas Mexicanas. México: Fondo de Cultura Econômica.

LANDA, D. de.

1986 Relación de las cosas de Yucatan. México: Porrúa.

LILLO MACINA, V.

2007 El Temazcalli mexicano, Su significación simbólica y su uso psicoterapéutico pasado y presente. México: Plaza y Valdés.

LIVI BACCI, M.

2005 Conquista. La distruzione degli indios americani. Bologna: Il Mulino.

LÓPEZ AUSTIN, A.

1989 Cuerpo Humano e Ideologia. Las concepciones de los Antiguos Nahuas. México: UNAM.

MONACO, E.

1997 Quetzalcoatl, Saggi sulla religione azteca. Roma: Bulzoni.

MOSQUERA SARAVIA, M.T. de J.

2001 Conociendo la Sabiduría Achí: Salud y Enfermedad en Rabinal. Guatemala: Servinprensa.

2002 La articulación de saberes Popolares y bio-medica entre las comadronas de Rabinal, Baja Verapaz. Universidade VRV, Departamento de Antropologia, tese de doutorado disponível on line: http://www.tdx.cbuc.es/TESIS_URV/ AVAILABLE/TDX-0122103-164843/
ROMEROS CONTRERAS, A.T.

2001 Visiones sobre el temazcal Mesoamericano: un elemento cultural polifacético. Ciencia Ergo Sum, Toluca, UNAM, 2: 133-144.

RUZ LHUILLIER, A.

1968 Costumbres funerarias de los Mayas. México: UNAM.

SAHAGÚN, B. de,

1999 Historia General de las cosas de Nueva España. México, Porrúa: Garibay A.M.K. (Ed).

SANTOS, E.N. dos

2005 "Calendário, cosmografia e cosmogonia nos códices e textos nahuas do século XVI". Tese de doutorado. Departamento de História da Faculdade de Filosofia, Letras e Ciências Humanas - Universidade de São Paulo, disponivel on line http://ged1.capes.gov.br/ CapesProcessos/919367-ARQ/ 919367_5.PDF

SCARDUELLI, P.

1980 Gli Aztechi e il sacrificio umano. Torino: Loescher.

SERNA, J. de la,

1952 Tratado de las idolatrias, supersticiones, Dioses, ritos, hechicerias y otras costumbres gentilicas de las razas aborigenes de México. Tomo X, México: Fuente Cultural.

SILVA PRADA, N.

2002 El uso de los baños temazcales en la visión de dos médicos novohispanos. Estudio introductorio y transcripción documental de los informes de 1689. Historia Mexicana, vol. LII, n. 001, Mexico: 5-56.

THOMPSON, J.E.

1995 Grandeza y Decadenza de los Maya. México: Fondo de Cultura Económica.

VILLATORO, E.M.

1994 La comadrona a través de la historia en las prácticas obstétricos pediátricas: una experiencia en el área Ixil Quichè. La Tradición Popular, 97: 1-21.

\section{WESTHEIM, P.}

1957 Ideas fundamentales del arte prehispánico en México. México: Fondo de Cultura Económica.

WILSON, R.

1999 Resurgimiento Maya en Guatemala. Antigua: CIRMA. 